\title{
EFFECTS OF CARDIOPULMONARY RESUSCITATION WITH AUTOMATED EXTERNAL DEFIBRILLATOR TRAINING AMONG SCHOOLCHILDREN IN SLOVENIA: A PRE- AND POST-TEST COHORT STUDY UČINKI IZOBRAŽEVANJA O TEMELJNIH POSTOPKIH OŽIVLJANJA $Z$ UPORABO AVTOMATSKEGA ZUNANJEGA DEFIBRILATORJA MED OSNOVNOŠOLCI V SLOVENIJI - KOHORTNA RAZISKAVA TIPA »PRED-PO«
}

\author{
Sanela PIVAČ ${ }^{1}$, Brigita SKELA-SAVIČ1 ${ }^{1}$ Primož GRADIŠEK ${ }^{2,3^{*}}$
}

\author{
${ }^{1}$ Angela Boškin Faculty of Health Care, Spodnji Plavž 3, 4270 Jesenice, Slovenia \\ 2University of Ljubljana, Faculty of Medicine, Department of Anaesthesiology and \\ Reanimatology, Vrazov trg 2, 1000 Ljubljana, Slovenia \\ ${ }^{3}$ University Medical Centre Ljubljana, Clinical Department of Anaesthesiology and \\ Intensive Therapy, Zaloška 7, 1000 Ljubljana, Slovenia
}

Received: Sep 25, 2020

Accepted: Feb 18, 2020

\section{ABSTRACT \\ Keywords: \\ cardiac arrest, basic life support, CPR, AED, nurses, education}

\section{IZVLEČEK}

Ključne besede:

srčni zastoj, kardiopulmonalno oživljanje, temeljni postopki oživljanja, TPO, AED, medicinske sestre, osnovne šole
Introduction: A low proportion of bystanders in Slovenia are willing to provide resuscitation to people experiencing cardiac arrest. We measured knowledge acquired after cardiopulmonary resuscitation training among Slovenian children in the final three grades of primary school.

Methods: This pre- and post-test cohort study included 566 schoolchildren aged 12-15 years. From April to May 2018, we administered a 15-item questionnaire to children in 15 primary schools, to assess the effects of theoretical and practical cardiopulmonary resuscitation training on their knowledge of cardiopulmonary resuscitation at 1-2 months after training. Data were processed using univariate, bivariate, and multivariate analyses.

Results: A significantly greater level of post-training knowledge was noted in all three equally sized school grade groups ( $p=0.001)$. The youngest group (mean age 12.5 years) exhibited the greatest increase in knowledge, with test scores increasing by an average 2.65 (range $0-15)$ points. Age $(p=0.001)$, body mass index $(p=0.037)$, female sex $(p=0.006)$, and previous resuscitation training $(p=0.024)$ were significant independent predictors of pretraining knowledge level. Sex was the only predictor significantly influencing knowledge levels after training $(p=0.002)$; girls scored up to 0.7 points higher than boys, both before and after training.

Conclusions: Among Slovenian schoolchildren aged 12-15 years, a significantly improved level of theoretical knowledge was demonstrated after cardiopulmonary resuscitation training. The introduction of cardiopulmonary training may be most effective in children aged 12.5 years (seventh graders). Early, compulsory resuscitation training might reduce social barriers to performing resuscitation, which may eventually translate into better post-cardiac arrest outcomes.

Uvod: V Sloveniji je delež laikov, ki so pripravljeni oživljati osebo v srčnem zastoju, majhen. Z namenom vpeljave obveznih izobraževalnih vsebin iz oživljanja v osnovne šole smo si zadali za cilj izmeriti stopnjo znanja, ki jo osnovnošolci $v$ zadnji triadi osnovne šole pridobijo po izobraževanju o temeljnih postopkih oživljanja z uporabo avtomatskega zunanjega defibrilatorja.

Metode: $V$ kohortni raziskavi tipa »pred-po«, ki je zajemala 566 učencev, starih med 12 in 15 let, smo z vprašalnikom, sestavljenim iz 15 vprašanj, v 15 šolah v obdobju od aprila do maja 2018 preverili učinek teoretičnega in praktičnega izobraževanja iz oživljanja na nivo znanja učencev dva meseca po izvedenem izobraževanju. Podatki so bili obdelani z univariatno, bivariatno in multivariatno analizo.

Rezultati: Stopnja znanja se je po izvedenem izobraževanju $v$ vseh treh po velikosti primerljivih razredih značilno izboljšala $(p=0,001)$. Največji napredek so dosegli učenci sedmega razreda, torej najmlajši (povprečna starost 12,5 let; $p=0,001$ ), ki so $v$ povprečju dosegli za 2,65 točk višjo oceno (razpon 0-15 točk). Neodvisni napovedni dejavniki nivoja znanja pred izvedenim izobraževanjem so bili starost $(p=0,001)$, indeks telesne mase $(p=0,037)$, ženski spol $(p=0,006)$ ter predhodna prisotnost na izobraževanju o oživljanju $(p=0,024)$; po izobraževanju pa je bil z nivojem znanja povezan le spol učencev $(p=0.002)$. Deklice so tako pred izobraževanjem kot po njem dosegle za 0,7 točk višjo oceno od dečkov.

Zaključek: $V$ veliki kohorti slovenskih osnovnošolcev, starih med 12 in 15 let, smo dokazali značilno višjo stopnjo teoretičnega znanja po izvedenem izobraževanju. Uvedba izobraževanja o temeljnih postopkih oživljanja je najbolj učinkovita pri 12,5 letih (7. razred osnovne šole). Zgodnja uvedba obveznega izobraževanja o temeljnih postopkih oživljanja bi lahko zmanjšala ovire pri nudenju oživljanja, kar bi dolgoročno lahko povečalo delež preživelih po srčnem zastoju.

\footnotetext{
*Corresponding author: Tel. + 3861522 7242; E-mail: primoz.gradisek@mf.uni-lj.si
} 


\section{INTRODUCTION}

Sudden cardiac arrest is a serious public health concern owing to its high mortality rate, high morbidity, and frequent disability among survivors (1). According to recent data, the rate of bystander cardiopulmonary resuscitation (CPR) in Slovenia is 30\%, ranking the country in the bottom third of all European nations (2). The most common reasons for bystander failure to provide CPR to individuals experiencing cardiac arrest include not recognizing cardiac arrest symptoms and lacking CPR knowledge (3), fear of contracting an infectious disease (4), and fear of making a mistake or causing an injury (5). Because early CPR is key to the survival of patients with cardiac arrest, many countries strive to increase the percentage of lay people who would provide CPR with the use of an automated external defibrillator (AED) (6). AEDs provide audio-visual instructions to initiate and guide CPR and can possibly improve CPR quality (7). According to some estimates, at least $15 \%$ of the population would have to be trained in CPR to achieve a significant increase in survival rates following cardiac arrest (8), a goal that is impossible to achieve with the existing amount of CPR training offered to adults in Slovenia. It is believed that mandatory CPR training of children in primary schools could help in reaching that goal; in addition to public health campaigns, such training has been proven to increase cardiac arrest survival rates $(6,8)$. CPR training should be offered in primary schools because, compared with adults, schoolchildren are more motivated to learn, can learn faster and are better able to retain the skills learned (9). In 1961, Norway was the first country in the world to include optional CPR training in the school curricula (10). In Europe, CPR training in primary schools is mandated by law in six countries (Belgium, Denmark, France, Italy, Portugal, and England), whereas others are still in the process of considering this option (11-15). The joint "Kids save lives" statement on training schoolchildren in CPR worldwide was launched by the European Resuscitation Council and other organizations, and endorsed by the World Health Organization in 2015. This statement recommends two hours of CPR training annually from the age of 12 years in all schools worldwide $(8,11)$.

Given the importance of early CPR training among children, we investigated pre- and post-training theoretical CPR knowledge in three age groups of schoolchildren to obtain evidence for introducing mandatory CPR training into the primary school curricula in Slovenia.

\section{METHODS}

\subsection{Design}

We used a cross-sectional cohort research method with a pre-post samples design to obtain quantitative data.

\subsection{Settings and participants}

This cross-sectional study was conducted from April to May 2018 in Slovenian primary schools where CPR training had previously been introduced. CPR training is not yet mandatory in the curricula of all Slovenian primary schools. Thus, we included all schoolchildren in the seventh, eighth, and ninth grades of 15 primary schools that provided CPR training in seven regions of Slovenia (Upper Carniola, Central Slovenia, Lower Sava, Central Sava, Carinthia, Savinja, and Mura). CPR training was provided by instructors with a background in nursing from 11 community health centres. The between-instructor variability in CPR knowledge and educational delivery methods was minimized by adherence to the national CPR training package, based on European Resuscitation Council guidelines (16). The training included a one-hour theoretical class and one-hour hands-on training using manikins.

Data was collected at two time points: first, knowledge levels were assessed in 764 of the 893 (85.6\%) included schoolchildren before CPR training; second, knowledge was re-assessed at one to two months after the CPR training in 566 of the $764(74.1 \%)$ schoolchildren who participated in the pre-training assessment. The pre- and post-training groups were similar in terms of sex and age distribution, parents' educational background, and body mass index (BMI). The cohort consisted of equal groups of children aged 12-15 years, and the mean ages of seventh, eighth, and ninth graders were $12.5,13.5$, and 14.5 years, respectively.

\subsection{Instrument}

The questionnaire was designed based on a literature review and recommendations for mandatory educational content by the National Institute of Public Health of Slovenia $(8,16-22)$. The instrument included a total of 49 items on an ordinal scale; items were divided into four sets, each containing different types of questions. The demographics section of the questionnaire included data on age, grade, month and year of birth, body weight, body height, and parental educational level. In total, 27 multiple-choice questions were used to assess knowledge regarding the phone number for medical emergencies and points to communicate to the emergency medical dispatch service, how to check for signs of life, proper chest compressions, use of an AED, and placement into the recovery position. In the CPR knowledge test, correct answers were assigned one point each, and an overall knowledge score was calculated to enable a comparison of the total knowledge. According to the final scores, respondents were ranked as follows: 13-15 points, excellent (90\%-100\%); $11-12$ points, very good $(75 \%-89 \%)$; 9-10 points, good (60\%-74\%); 7-8 points, satisfactory (45\%$59 \%)$; and 6 points or less, unsatisfactory $(<44 \%)$. Validity of the instrument was confirmed by ensuring that the items were clearly formulated, and their understanding 
was checked in a pilot study (npre training=66; npost training=64). Additional instructions were provided for questions where more than one answer was correct, to clarify the question and to explicitly state the number of correct answers (23).

\subsection{Data analysis}

The quantitative data thus obtained was processed using IBM SPSS Statistics 22.0 (IBM Corp., Armonk, NY, USA). Descriptive statistics and bivariate analysis were used (chisquare test and one-way analysis of variance). Linear and multiple regression analyses were conducted to examine the relationships between the dependent variable of knowledge and the independent variables. Regression models included only those variables for which statistical correlation with dependent variables was confirmed in advance. The level of statistical significance was set at $p \leq 0.05$.

\section{RESULTS}

Compared with the level of CPR knowledge before training, the level of knowledge after training increased to an average score of 11.62 (standard deviation [SD]=2.04) among seventh graders, to $11.44(\mathrm{SD}=2.11)$ among eighth graders, and to 11.52 ( $(\mathrm{SD}=2.00)$ among ninth graders. The scores improved significantly during the second assessment for all grades $(p=0.001$ for all three grades of primary school). In the post-training assessment, the level of knowledge was comparable among seventh, eighth, and ninth graders $(p=0.693)$; however, the progress made differed significantly among the three grades $(p=0.001)$. The greatest progress in knowledge was seen among seventh graders, who improved their results by an average of 2.65 points out of a total of 15 points (Table 1 ).
The distribution of rankings of schoolchildren before and after CPR training is shown in Figure 1. For the entire cohort, the percentage of children who were ranked excellent increased from $5.9 \%$ to $35.2 \%$, and the percentage of those who were ranked very good increased from $28.4 \%$ to $38.2 \%$. Moreover, fewer children were ranked in the categories good, satisfactory, and unsatisfactory after CPR training.

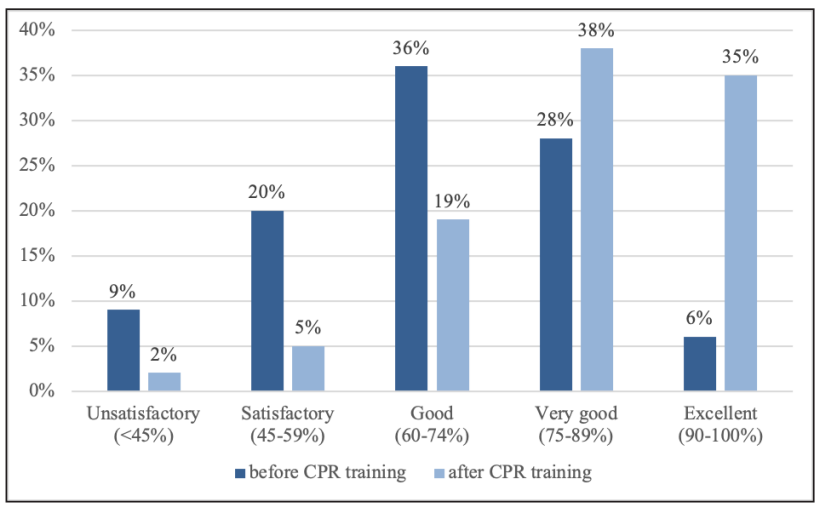

Figure 1. Knowledge rankings achieved before and after CPR training in 566 schoolchildren aged $12-15$ years.

Table 2 shows the knowledge rankings according to different grades. A statistically significant improvement in knowledge rankings was noted among children in all three primary school grades included in the study $(p<0.005$ for all). After training, the scores obtained by seventh graders were comparable to those of the eighth and ninth graders. Seventh graders comprised most respondents who were categorized as having very good or excellent CPR knowledge after training (38.9\% and $36.8 \%$, respectively).

Table 1. Schoolchildren's level of CPR knowledge before and after CPR training according to grade.

\begin{tabular}{|c|c|c|c|c|c|c|c|c|c|c|}
\hline & & \multicolumn{3}{|c|}{$\begin{array}{l}\text { Before CPR training } \\
\qquad(n=762)\end{array}$} & \multicolumn{3}{|c|}{$\begin{array}{l}\text { After CPR training } \\
\qquad(n=566)\end{array}$} & \multicolumn{2}{|c|}{$\begin{array}{l}\text { Average difference } \\
\text { (pre-post CPR training } \\
\text { for each grade) }\end{array}$} & \multirow{2}{*}{$\begin{array}{c}\text { P-value } \\
\text { t-test } \\
\text { (pre-post CPR training } \\
\text { for each grade) }\end{array}$} \\
\hline & & $n$ & $M$ & SD & $n$ & $M$ & SD & $M$ & SD & \\
\hline $\begin{array}{l}7^{\text {th }} \text { grade } \\
12.5 \text { years }\end{array}$ & $\begin{array}{l}\text { Knowledge of CPR } \\
\text { with the use of an AED }\end{array}$ & 244 & 8.97 & 2.20 & 185 & 11.62 & 2.04 & 2.65 & 0.21 & $0.001^{*}$ \\
\hline $\begin{array}{l}8^{\text {th }} \text { grade } \\
13.5 \text { years }\end{array}$ & $\begin{array}{l}\text { Knowledge of CPR } \\
\text { with the use of an AED }\end{array}$ & 254 & 9.37 & 1.99 & 174 & 11.44 & 2.11 & 2.07 & 0.20 & $0.001^{*}$ \\
\hline $\begin{array}{l}9^{\text {th }} \text { grade } \\
14.5 \text { years }\end{array}$ & $\begin{array}{l}\text { Knowledge of CPR } \\
\text { with the use of an AED }\end{array}$ & 264 & 10.04 & 2.04 & 207 & 11.52 & 2.00 & 1.48 & 0.19 & $0.001^{*}$ \\
\hline \multicolumn{2}{|c|}{$\begin{array}{l}\text { p-value one-way ANOVA } \\
\text { (according to grades) }\end{array}$} & \multicolumn{3}{|c|}{$0.001^{* *}$} & & 0.693 & & \multicolumn{2}{|c|}{$0.001^{* *}$} & \\
\hline
\end{tabular}

Note: $\mathrm{n}$ = number of schoolchildren, $\mathrm{M}=$ mean value, $\mathrm{SD}=$ standard deviation (total score for the CPR knowledge test on a scale from 0 to 15$)$; *Improvement in knowledge before and after training for each grade is statistically significant $(p<0.05),{ }^{* *}$ Difference between grades before training is statistically significant $(p<0.05)$ 
Table 2. Ranking of schoolchildren's knowledge before and after CPR training according to grade.

\begin{tabular}{|c|c|c|c|c|c|c|c|}
\hline & \multirow[t]{2}{*}{ CPR knowledge } & & \multicolumn{2}{|c|}{ Before CPR training } & \multicolumn{2}{|c|}{ Post CPR training } & \multirow{2}{*}{$\begin{array}{l}\text { Chi-square test } \\
\text { (p-value) }\end{array}$} \\
\hline & & & $\mathrm{n}$ & $f(\%)$ & $\mathrm{n}$ & $f(\%)$ & \\
\hline \multirow[t]{5}{*}{$7^{\text {th }}$ grade } & Unsatisfactory & $<44 \%$ & 33 & 13.5 & 2 & 1.1 & 126.609 \\
\hline & Satisfactory & $45-59 \%$ & 67 & 27.5 & 13 & 7.0 & 0.001 \\
\hline & Good & $60-74 \%$ & 76 & 31.1 & 30 & 16.2 & \\
\hline & Very good & $75-89 \%$ & 60 & 24.6 & 72 & 38.9 & \\
\hline & Excellent & $90-100 \%$ & 8 & 3.3 & 68 & 36.8 & \\
\hline \multirow[t]{5}{*}{$8^{\text {th }}$ grade } & Unsatisfactory & $<44 \%$ & 25 & 9.8 & 4 & 2.3 & 101.507 \\
\hline & Satisfactory & $45-59 \%$ & 46 & 18.1 & 11 & 6.3 & 0.001 \\
\hline & Good & $60-74 \%$ & 105 & 41.3 & 34 & 19.5 & \\
\hline & Very good & $75-89 \%$ & 70 & 27.6 & 65 & 37.4 & \\
\hline & Excellent & $90-100 \%$ & 8 & 3.1 & 60 & 34.5 & \\
\hline \multirow[t]{5}{*}{$9^{\text {th }}$ grade } & Unsatisfactory & $<44 \%$ & 12 & 4.5 & 4 & 1.9 & 54.860 \\
\hline & Satisfactory & $45-59 \%$ & 43 & 16.3 & 10 & 4.8 & 0.001 \\
\hline & Good & $60-74 \%$ & 93 & 35.2 & 43 & 20.8 & \\
\hline & Very good & $75-89 \%$ & 87 & 33.0 & 79 & 38.2 & \\
\hline & Excellent & $90-100 \%$ & 29 & 11.0 & 71 & 34.3 & \\
\hline
\end{tabular}

Note: $\mathrm{n}=$ number of schoolchildren; $\mathrm{f}(\%)$ = percentages; *The difference in pre-post knowledge for a grade is statistically significant $(p<0.05)$.

The proportion of explained variance of the final score obtained on the pre-training test was $4.6 \%\left(R^{2}=0.046\right)$, and this model was thus acceptable and significant $(F=6.089$, $p<0.001)$. Children with a higher mean age $(B=0.128$, $p=0.001)$, girls $(B=-0.109, p=0.006)$, children with a higher BMI $(B=0.081, p=0.037)$, and those who had previously participated in CPR training $(B=0.090, p=0.024)$ showed greater knowledge levels. In the predictive post-training model, few independent variables were suitable for inclusion. Although the model was statistically significant $(F=9.036 ; p=0.004)$, it explained $4.4 \%$ of the knowledge level variance $\left(R^{2}=0.044\right)$, and girls had greater knowledge after training than boys $(B=-0.119, p=0.002)$. Both before and after CPR training, girls' final test scores were up to 0.7 points higher than those of boys $(B=-0.447$ and $\mathrm{B}=-0.704$, respectively) (Table 3 ).

Table 3. Regression analysis for the impact of sociodemographic and CPR variables on the level of knowledge.

\begin{tabular}{|c|c|c|c|c|c|c|c|c|c|}
\hline & & \multicolumn{2}{|c|}{$\begin{array}{l}\text { Unstandardized } \\
\text { coefficients }\end{array}$} & \multirow{2}{*}{$\begin{array}{c}\begin{array}{c}\text { Standardized } \\
\text { coefficients }\end{array} \\
\text { B }\end{array}$} & \multirow[b]{2}{*}{$\mathrm{t}$} & \multirow{2}{*}{$\begin{array}{l}\text { Confidence interval } \\
\text { for B (lower bound - } \\
\text { upper bound) }\end{array}$} & \multirow[b]{2}{*}{ P-value } & \multirow[b]{2}{*}{$F(p)$} & \multirow[b]{2}{*}{$\mathbf{R}^{2}$} \\
\hline & & B & Standard error & & & & & & \\
\hline \multirow{7}{*}{ 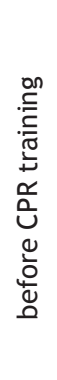 } & constant & 4.244 & 1.293 & & 3.284 & 1.7066 .783 & 0.001 & 6.089 & 0.046 \\
\hline & age* & 0.274 & 0.084 & 0.128 & 3.260 & 0.1090 .439 & 0.001 & $(<0.001)$ & \\
\hline & BMI* & 0.051 & 0.024 & 0.081 & 20.86 & 0.0030 .099 & 0.037 & & \\
\hline & gender* & -0.447 & 0.162 & -0.109 & -2.765 & $-0.765-0.130$ & 0.006 & & \\
\hline & $\begin{array}{l}\text { maternal educational } \\
\text { achievement }\end{array}$ & 0.173 & 0.101 & 0.067 & 1.718 & -0.0250 .370 & 0.086 & & \\
\hline & previous CPR training* & 0.398 & 0.175 & 0.090 & 2.270 & 0.0540 .742 & 0.024 & & \\
\hline & $\begin{array}{l}\text { previous viewing } \\
\text { of a CPR film }\end{array}$ & 0.299 & 0.165 & 0.072 & 1.812 & -0.0250 .623 & 0.070 & & \\
\hline \multirow{4}{*}{ 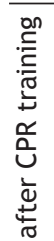 } & constant & 10.907 & 0.334 & & 32.608 & 10.25011 .564 & $<0.001$ & 9.036 & 0.044 \\
\hline & gender* & -0.704 & 0.172 & -0.176 & -4.104 & $-1.041-0.367$ & $<0.001$ & $(<0.001)$ & \\
\hline & $\begin{array}{l}\text { paternal educational } \\
\text { achievement }\end{array}$ & 0.116 & 0.122 & 0.046 & 0.955 & -0.1230 .355 & 0.340 & & \\
\hline & $\begin{array}{l}\text { maternal educational } \\
\text { achievement* }\end{array}$ & 0.269 & 0.117 & 0.111 & 2.298 & 0.0390 .498 & 0.022 & & \\
\hline
\end{tabular}

Note: Dependent variable $=$ total score on the test (number of correct answers), $\mathrm{B}=$ regression coefficient, $\mathrm{B}=$ standardized regression coefficient, $t=t$-statistics, $F=F$-statistics, $p$ = significance, $R^{2}=$ share of explained variance

${ }^{*}$ The influence of a variable on the level of knowledge is statistically significant $(p<0.05)$ 


\section{DISCUSSION}

In this study, we examined the impact of a single two-hour theoretical and practical CPR training on the level of CPR knowledge, assessed one to two months after training, in a large sample of Slovenian schoolchildren enrolled in the final three grades of primary school (aged 12-15 years). The main finding of this study is that the implementation of CPR training was most effective at the age of 12.5 years (seventh graders). Greater CPR knowledge was associated with previous training, and thus continuous CPR education should be introduced into school curricula.

CPR education among schoolchildren increases the rate of bystander CPR and improves survival after cardiac arrest. Convincing data in this regard is reported from Denmark, where mandatory CPR education was implemented in 2005 (6), and from the United States, where the American Heart Association advocated compulsory CPR training in all American schools nine years ago (24). The optimal age proposed by the European Resuscitation Council to begin CPR training is 12 years old (8). The American Heart Association recommends that CPR be taught from as early as age 9 years, although at that age schoolchildren can only learn certain aspects of CPR (24). It has been shown that schoolchildren aged 7 to 10 years are sufficiently able to recognize the signs of cardiac arrest and understand the importance of CPR and the use of AEDs (25-27). Owing to having a lower BMI, the depth of chest compressions provided by children in this age group is insufficient; however, they are as successful as their older peers in the frequency of chest compressions provided and the correct CPR sequence $(25,28)$. Some authors have found that younger schoolchildren are as successful as their older peers in providing chest compressions and in attaining adequate theoretical CPR knowledge, on the condition that they receive continuous CPR training (19, 27). Nevertheless, data regarding the most appropriate age to start teaching different components of CPR are inconsistent because most evidence mainly focuses on the physical ability to perform practical CPR skills $(25,26,29)$. In general, our study revealed a moderate level of pretraining theoretical knowledge in cardiac arrest and CPR principles (mean score $9.46 \pm 2.08$, maximum score 15 ). Baseline theoretical CPR knowledge prior to training, using a 15-item questionnaire, was greatest in ninth graders (average age 14.5 years) and lowest in seventh graders (average age 12.5 years); similar findings have been reported in most other studies conducted among schoolchildren $(19,25)$.

At 1 to 2 months after CPR training, a significant improvement in the level of theoretical knowledge remained among students in all three observed grades. Surprisingly, children in all grades had a comparable level of knowledge (mean score $11.53 \pm 2.05$, maximum score 15).
After CPR training, most participating schoolchildren were categorized as having very good or excellent knowledge, which is in sharp contrast to the pre-training findings where most children were categorized as having good, satisfactory, or unsatisfactory knowledge. Although the effect of CPR training with the use of an AED on theoretical knowledge among the participants is evident, one would expect the differences in knowledge established before training between different grades to also be reflected after training. The number of correct answers in the written test two months after training increased by $17.5 \%$, $13 \%$, and $9.8 \%$ among the seventh, eighth, and ninth graders, respectively. This means that the effect of CPR training on improvement in CPR knowledge was inversely proportional to the age of schoolchildren; the observed improvement in theoretical knowledge scores was highest among seventh graders, as supported using exploratory statistical methods rather than explanatory methods. We can thus conclude that younger schoolchildren are more influenced by theoretical content related to resuscitation and the implementation of CPR with an AED. In contrast, some authors have found that schoolchildren aged over 13 years were more successful in solving theoretical tests after training than their younger peers $(19,25,26)$. Although our study showed that the level of knowledge after CPR training was comparable for different grades (seventh graders did not achieve higher scores than eighth and ninth graders), it is nevertheless advisable to begin CPR training in the use of an AED among younger children, as suggested in previous research $(20,24,27,30)$. This is because younger schoolchildren are better able to learn practical CPR interventions than their older peers (26), and also because early training reduces anxiety about making mistakes and considerably increases participants' willingness to help (19). In general, continuous training helps with retaining the same level of knowledge, although a six-year longitudinal analysis carried out in Germany showed that resuscitation skills were retained even when training was interrupted for three years (26). The correlation between previous CPR training with the use of an AED and level of knowledge in our study suggests that CPR training should be provided continuously, preferably as a brief annual refresher training. Strong interaction effects of training frequency were seen in both CPR knowledge level and chest compression depth (19). CPR training in the use of an AED must be adapted to schoolchildren's age and gender (31, 32), and modern teaching approaches, such as self-instruction kits and computer-based learning, should be used. Preferably, CPR training should be conducted by school nurses whenever possible, or by schoolteachers with experience of teaching CPR (27). The German Resuscitation Council has proposed an exemplary model curriculum for primary schools based on children's cognitive and psychomotor development, in which the training content and goals are arbitrarily divided 
into three age groups (8-10, 11-14, and 15-18 years) (31). Although these recommendations were issued eight years ago, Germany had not yet adopted CPR legislation at the time of the present study (11).

A higher level of CPR knowledge prior to CPR training was noted in older schoolchildren, those with a higher BMI, girls, those who had previously attended CPR training, and schoolchildren whose mothers had higher educational achievement. Girls had higher levels of knowledge than boys both before and after CPR training. Better motivation and attitudes toward CPR and better theoretical CPR performance in girls compared with boys were demonstrated in a recent review, suggesting that sex-related aspects need to be addressed in CPR training program in schools (33). The correlation between higher maternal educational achievement and higher levels of CPR knowledge among schoolchildren might suggest that children whose mothers have a higher level of education tend to have a more positive attitude toward education, place a higher value on knowledge, have higher expectations of themselves, greater awareness about the importance of skills in resuscitation, and feel socially responsible to conduct CPR. However, these assumptions were not investigated in our study, and should be further explored.

\subsection{Strengths and limitations}

This was the first study in the region to evaluate knowledge before and after CPR training in a population of schoolchildren aged 12-15 years. The results provide additional evidence for public health policy-makers to implement compulsory CPR training in primary schools. Our quantitative study included a large sample of schoolchildren; however, our study was not designed to measure pre- and post-training practical skills. For a more objective assessment of CPR performance, a theoretical and structured practical knowledge evaluation would need to be conducted in a simulated setting, preferably at different time points after CPR training, to measure retention of knowledge and skills. In this study, the correlations established in quantitative research were weak, as were the levels of explained variance in regression; therefore, these findings represent a basis for future research, both in terms of selected methods and sampling. Further research is needed to investigate additional factors that could better explain CPR knowledge, thus improving predictor reliability. Finally, the influence of sex and maternal educational achievement on CPR knowledge among schoolchildren should be investigated further.

\section{CONCLUSIONS}

This study demonstrated a marked improvement in the post-training levels of theoretical CPR knowledge in a large cohort of schoolchildren aged 12-15 years. Because the greatest increase in knowledge was observed among seventh graders, CPR training should be introduced to children at a mean age of 12.5 years (i.e., seventh graders). Previous research has shown that bystanders fail to recognize cardiac arrest and to provide assistance owing to a lack of knowledge and fear of performing resuscitation procedures. In addition to increased knowledge, early and compulsory CPR training during childhood can induce long-term behavioural changes and reduce anxiety around making mistakes, which could translate into better outcomes for survivors of cardiac arrest.

\section{CONFLICTS OF INTEREST}

The authors declare that they have no competing interests with regard to this research.

\section{FUNDING}

This research did not receive any specific grant from funding agencies in the public, commercial, or not-forprofit sectors.

\section{ETHICS APPROVAL}

Written consent to conduct and implement the research was obtained from the Slovenian National Medical Ethics Committee on June 28, 2017 (0120-269/2017-4; KME 41/05/17). Letters of consent on participants' behalf were obtained from participating schools and community health centres, as well as from the parents of child respondents. Anonymity of the research participants was ensured.

\section{REFERENCES}

1. Sasson C, Meischke H, Abella BS, Berg RA, Bobrow BJ, Chan PS, et al. Increasing cardiopulmonary resuscitation provision in communities with low bystander cardiopulmonary resuscitation rates: a science advisory from the American Heart Association for Healthcare Providers, Policymakers, Public Health Departments, and Community Leaders. Circulation. 2013;127:1342-50. doi: 10.1161/CIR.0b013e318288b4dd.

2. Gräsner JT, Lefering R, Koster RW, Masterson S, Böttiger BW, Herlitz $\mathrm{J}$, et al. EuReCa ONE-27 Nations, ONE Europe, ONE Registry: A prospective one month analysis of out-of-hospital cardiac arrest outcomes in 27 countries in Europe. Resuscitation. 2016;105:188-95. doi: 10.1016/j.resuscitation.2016.06.004.

3. Nolan JP, Soar J, Zideman DA, Biarent D, Bossaert LL, Deakin C, et al. European Resuscitation Council Guidelines for Resuscitation 2010 Section 1. Executive summary. Resuscitation. 2010;81:1219-76. doi: 10.1016/j.resuscitation.2010.08.021. 
4. Becker LB, Berg RA, Pepe PE, Idris AH, Aufderheide TP, Barnes TA, et al. A reappraisal of mouth-to-mouth ventilation during bystanderinitiated cardiopulmonary resuscitation. A statement for healthcare professionals from the Ventilation Working Group of the Basic Life Support and Pediatric Life Support Subcommittees, American Heart Association. Circulation. 1997;96:2102-12. doi: 10.1161/01. cir.96.6.2102.

5. Chamberlain D, Smith A, Colquhoun M, Handley AJ, Kern KB, Woollard $M$. Randomised controlled trials of staged teaching for basic life support: 2. Comparison of CPR performance and skill retention using either staged instruction or conventional training. Resuscitation. 2001;50:27-37. doi: 10.1016/s0300-9572(01)00342-2.

6. Sondergaard KB, Wissenberg M, Gerds TA, Rajan S, Karlsson L, Kragholm K, et al. Bystander cardiopulmonary resuscitation and longterm outcomes in out-of-hospital cardiac arrest according to location of arrest. Eur Heart J. 2019;40:309-18. doi: 10.1093/eurheartj/ehy687.

7. Malta Hansen C, Rosenkranz SM, Folke F, Zinckernagel L, TjørnhøjThomsen T, Torp-Pedersen C, et al. Lay Bystanders' Perspectives on What Facilitates Cardiopulmonary Resuscitation and Use of Automated External Defibrillators in Real Cardiac Arrests. J Am Heart Assoc. 2017;6:e004572. doi: 10.1161/JAHA.116.004572.

8. Böttiger BW, Van Aken H. Kids save lives-training school children in cardiopulmonary resuscitation worldwide is now endorsed by the World Health Organization (WHO). Resuscitation. 2015;94:A5-A7; doi: 10.1016/j.resuscitation.2015.07.005.

9. Jones I, Whitfield R, Colquhoun $M$, Chamberlain D, Vetter $N$, Newcombe R. At what age can schoolchildren provide effective chest compressions? An observational study from the Heartstart UK schools training programme. BMJ. 2007;334(7605):1201. doi: 10.1136/ bmj.39167.459028.DE.

10. Lind B, Stovner J. Mouth to mouth resuscitation in Norway. J Am Med Assoc. 1963;185:933-5. doi: 10.1001/jama.1963.03060120043019.

11. Böttiger BW. "A Time to Act" - Anaesthesiologists in resuscitation help save 200,000 lives per year worldwide: school children, lay resuscitation, telephone - CPR, IOM and more. Eur J Anaesthesiol. 2015;32:825-7; doi: 10.1097/EJA.0000000000000374.

12. Semeraro F, Wingen S, Schroeder DC, Ecker $H$, Scapigliati A, Ristagno G, et al. Kids save lives-Three years of implementation in Europe. Resuscitation. 2018;131:e9-e11. doi: 10.1016/j. resuscitation.2018.08.008.

13. Lester CA, Weston CFM, Donnelly PD, Assar D, Morgan MJ. The need for wider dissemination of CPR skills: are schools the answer? Resuscitation. 1994;28:233-7. doi: 10.1016/0300-9572(94)90069-8.

14. Miró O, Jiménez-Fábrega X, Espigol G, Culla A, Escalada-Roig X, Díaz $\mathrm{N}$, et al. Teaching basic life support to 12-16 year olds in Barcelona schools: views of head teachers. Resuscitation. 2006;70:107-16. doi: 10.1016/j.resuscitation.2005.11.015.

15. Mpotos N, Vekeman E, Monsieurs K, Derese A, Valcke M. Knowledge and willingness to teach cardiopulmonary resuscitation: a survey amongst 4273 teachers. Resuscitation. 2013;84:496- 500. doi: 10.1016/j.resuscitation.2013.01.023.

16. Šalda Z, Zidar N. Temeljni postopki oživljanja z uporabo AED kot del vzgoje za zdravje. Ljubljana: Nacionalni inštitut za javno zdravje; 2017. Accessed March 7th, 2020 at: http://www.nijz.si/sites/www. nijz.si/files/publikacije-datoteke/temeljni_postopki_ozivljanja.pdf.

17. Frederick K, Bixby E, Orzel MN, Stewart-Brown S, Willett K. An evaluation of the effectiveness of the Injury Minimization Programme for Schools (IMPS). Inj Prev. 2000;6:92-5. doi: 10.1136/ip.6.2.92.

18. Van de Velde $S$, Heselmans A, Roex A, Vandekerckhove P, Ramaekers D, Aertgeerts B. Effectiveness of nonresuscitative first aid training in laypersons: a systematic review. Ann Emerg Med. 2009;54:447-57. doi: 10.1016/j.annemergmed.2008.11.005.

19. Bohn A, Van Aken HK, Möllhoff T, Wienzek H, Kimmeyer P, Wild E, et al. Teaching resuscitation in schools: annual tuition by trained teachers is effective starting at age 10. A four-year prospective cohort study. Resuscitation. 2012;83:619-25. doi: 10.1016/j. resuscitation.2012.01.020.
20. Meissner TM, Kloppe C, Hanefeld C. Basic life support skills of high school students before and after cardiopulmonary resuscitation training: a longitudinal investigation. Scand J Trauma Resusc Emerg Med. 2012;20:1-7. doi: 10.1186/1757-7241-20-31.

21. Petrić J, Malički M, Marković D, Meštrović J. Students' and parents' attitudes toward basic life support training in primary schools. Croat Med J. 2013;54:376-80. doi: 10.3325/cmj.2013.54.376.

22. Calicchia S, Cangiano G, Capanna S, De Rosa M, Papaleo B. Teaching Life-Saving Manoeuvres in Primary School. Biomed Res Int. 2016;2016:2647235. doi: 10.1155/2016/2647235.

23. Urh I. Anketiranje kot tehnika zbiranja podatkov v zdravstveni negi: preizkušanje anketnega vprašalnika. Obzor Zdr N. 2003;37:219-24.

24. Cave DM, Aufderheide TP, Beeson J, Ellison A, Gregory A, Hazinski MF, et al. Importance and implementation of training in cardiopulmonary resuscitation and automated external defibrillation in schools: a science advisory from the American Heart Association. Circulation. 2011;123:691-706. doi: 10.1161/CIR.0b013e31820b5328.

25. Banfai B, Pek E, Pandur A, Csonka H, Betlehem J. 'The year of first aid': effectiveness of a 3-day first aid programme for 7-14-year-old primary schoolchildren. Emerg Med J. 2017;34:526-32. doi: 10.1136/ emermed-2016-206284.

26. Lukas RP, Van Aken H, Mölhoff T, Weber T, Rammert M, Wild E, et al. Kids save lives: a six-year longitudinal study of schoolchildren learning cardiopulmonary resuscitation: who should do the teaching and will the effects last? Resuscitation. 2016;101:35-40. doi: 10.1016/j. resuscitation.2016.01.028.

27. Plant N, Taylor K. How best to teach CPR to schoolchildren: a systematic review. Resuscitation. 2013;84:415--21. doi: 10.1016/j. resuscitation.2012.12.008.

28. Berthelot S, Plourde M, Bertrand I, Bourassa A, Couture M.-.M, Berger-Pelletier $E$, et al. Push hard, push fast: quasi-experimental study on the capacity of elementary schoolchildren to perform cardiopulmonary resuscitation. Scand J Trauma Resusc Emerg Med. 2013;21:41. doi: 10.1186/1757-7241-21-41.

29. Bollig G, Myklebust AG, Østringen K. Effects of first aid training in the kindergarten--a pilot study. Scand J Trauma Resusc Emerg Med. 2011;19:13. doi: 10.1186/1757-7241-19-13.

30. Shahab N, Rashad S, Syed AH, Hanniyah B, Hafsa A, 2011. School children training or basic life support. J Coll Physicians Surg Pak. 2011;21:611-5. doi: 10.2011/JCPSP.611615.

31. Altemeyer KH, Breckwoldt J, Dirks B, Goldschmidt P, Huth R, Kreimeier $\mathrm{U}$, et al. Recommended curriculum to teach and train resuscitation to school children in Germany, 2012. GRC \& BAGEH: Resuscitation training for school children. Accessed April 7th, 2020 at: https://www. grc-org.de/downloads/GRC-school_curriculum_ATEE_12-10_JB.pdf.

32. Puc J, Obadić P, Erčulj V, Borovečki A, Grosek Š. A Cross-sectional Study Among Healthcare and Non-healthcare Students in Slovenia and Croatia About Do-not Resuscitate Decision-making. Zdr Varst. 2019;58:139-47. doi: 10.2478/sjph-2019-0018.

33. Finke SR, Schroeder DC, Ecker H, Wingen S, Hinkelbein J, Wetsch WA, et al. Gender aspects in cardiopulmonary resuscitation by schoolchildren: A systematic review. Resuscitation. 2018;125:70-8. doi: 10.1016/j.resuscitation.2018.01.025. 